\title{
Appraisal of the physics education programme in the National Open University of Nigeria
}

\author{
Jamiu Oluwadamilare Amusa \\ ORCID ID: 0000-0002-4739-9632
}

Department of Science Education, National Open University of Nigeria, Abuja, Nigeria

Corresponding author contact: jamusa@noun.edu.ng

\begin{abstract}
The general apathy towards the study of physics education among the prospective science teachers can once again be raised as the National Open University of Nigeria marks its $15^{\text {th }}$ years of providing functional, cost effective and life-long education to a very large number of Nigerians yearning for university education. Physics Education is arguably one of the few courses that gain the lowest patronage among science students across Nigerian universities. Hence, the discouraging phenomenon of low enrollment is not peculiar to NOUN. The case also becomes more disturbing when the study of physics education in an open and distance-learning environment becomes much more abstract than where you actuallyculturally see the lecturer each time there is a class as it operates in the conventional university system. The challenge of sustaining physics education in the open and distance environment needs to be addressed towards improving enrollment of students into the programme. The paper has adopted a theoretical approach which examined the sequence of events as regard physics education in the past fifteen years of the existence of the National Open University of Nigeria. The challenges and prospects of this programme, which is at the centre of the nation's scientific and technological independence were critically x-rayed in the light of current realities. Anong otherWithin the proposed set of recommendations proffered, it was further suggested that the NOUN advocacy team, in collaboration with the Department of Science Education should take sensitization and awareness campaign to secondary school science students particularly on the prospects of enrolling into physics education programme.
\end{abstract}

Keywords: Physics Education, Open and Distance Education, Physics Teachers.

\section{Introduction}

One of the major physical sciences offered in Nigeria secondary school is physics. Due to its numerous benefits towards attaining scientific and technological reliance (Amadalo, Ocholla, \& Memba, 2012; Ogunleye, 2009), it was introduced into Nigerian secondary schools as stated in the curriculum document of 1985 by Federal Ministry of Education (FME) and revised in 1998 and 2011 with the following objectives:

(i) To provide basic literacy in physics for functional living in the society.

(ii) To acquire basic concepts and principles of physics as a preparation for further studies.

(iii) To acquire essential scientific skills and attitudes as a preparation for the technological application of physics and

(iv) To stimulate and enhance creativity

Thus, to enhance national development in information, science, technology and innovation, basic concepts and principles of physics are highly indispensable. Physics, in the words of Jegede and Adedayo (2013), is theplays a pivotal subjectrole in technology. The art of teaching of-physics in the at school, as an integral part of the scientific education, is referred to as physics education.

Physics education is the theory and method of teaching physics within the science curriculum. It is a combination of physics content and the relevant pedagogical strategies in instructional delivery. The theories and methods developed in this field of study will enhance teachers' effectiveness and versatility in the process of teaching physics in the classroom (Amusa, 2015). Professional physics educators are trained at higher institutions of learning that run programme in physics education for content knowledge and skills 
acquisition in the scientific process (Ogunleye, 2012). It could either be at the university level or at the level of college of education. It is important to note that college of education certificate is no longer adequate to enable effective teaching at the secondary school level in this modern age of technology (Ogunleye, 2010). Hence, the need for university degree among science education teachers becomes highly imperative. In the past, some universities run dual mode of education delivery - conventional and distance learning system. Satellite campuses became the ether order of the day with no commensurate quality in higher education. With the reform that was carried out by the National Universities Commission (NUC), National Open University of Nigeria was established in 2002 with the mandate to run open and distance education, primarily to adult learners seeking higher education.

Science educators, with specific reference to physics teachers, who are active in the teaching profession found a solace in NOUN to pursue further degree at their pace, convenience and according to available funds. It is however unfortunate that the enrollment into physics education degree programme since in ception of-NOUN's establishment has not been encouraging. The initial misconceptions about NOUN degree programmes, general misunderstanding on the practicability of open and distance education and the existing phobia for physics as a science subject and the wrong notion about the quality of ODL programmes generally were considered as some of the major reasons militating against significant enrollment into physics education programme. It was inconceivable that learning could be possible, especially science subjects, without the physical presence of the teacher due to the practical nature of the subject and the perceived roles of the teacher in science instruction (Ogunleye, 2012). This notion has however been proved wrong with the emergence of varied e-learning tools on information and communication technology (ICT) (Ogunleye, 2009) which broke the physical barriers between the teachers and the learners and established the reality of virtual world (Ogunleye \& Apata, 2018). It is however essential to make it clear that distance education is as old as Nigerian Independence. The emergence of NOUN however opened up what was hitherto considered as a closed-circuit system of education and brought Nigerian closer to a functional and life-long education with over seventy study centres spread across communities and cities in Nigeria. Despite this level of openness, why has physics education taken the back position with low enrollment of students with the scenario of low physics enrolment in NOUN and trace the issue back to the situation in secondary schools as compared with Biology and chemistry over the years (Ogunleye, 2011)

\section{Explaining Open and Distance Learning}

Literature is replete with literal, contextual and conceptual definition of open and distance learning, or open and distance education (Ogbeide 2019). Terhemba (2007) described ODL as teaching and learning process in which students are separated from the teacher by a physical distance which is often bridged by a well-defined and relevant information and communication technology tools. Perraton (2001) and Onwe, (2015) epined-argued that distance education is an educational process in which significant proportion of the teaching (facilitation) is conducted by someone (facilitator) that is removed in space and time from the learner. The link between the facilitator and the learner is therefore necessarily provided by different means of communication and instruction. One fundamental feature of distance education is the high level of its learner-centeredness. A learner-centered educational process according to Terhemba (2007) is departing from a conventional teaching and learning culture where learners have direct interaction with the teacher at a predefined time and place, towards ene, a culture which that employs a wide range of technological tools to effect achieve the intended learning outcomes. The technology tool in the $21^{\text {st }}$ century is majorly-primarily a computer-based system with functional internet connectivity. With this singular device, learners can be linked to a very vast electronic courseware, access online video lectures, watch recorded practical classes, attend to tutor marked assignment (TMA), link up with facilitators through email and other social media platforms at any convenient time and place. Keegan (1993) cited in Terhemba (2007) described open and distance education with the following characteristics - separation of teachers from learners, use of communication technologies to link the teachers, curriculum content and the learners, and enhancement of two-way communication. In his contribution, Jegede (2013) argued that open and distance education can accommodate diverse learning style, and provide unrestricted access to remote and normally inaccessible people or group in different circumstances. One of such groups are the inmates in the Nigeria Correctional Services (Nigerian Prison Services)

\section{Historical Perspective of NOUN within the Global ODL Framework}


The Education for All (EFA) pact signed by Nigeria as a member of United Nation received a tremendous boost in 1983 when open and distance learning (ODL), also referred to as open and distance education (ODE) was rejuvenated and introduced into Nigerian Higher Education System through the inauguration of National Open University of Nigeria, NOUN. Since then, the landscape of higher education in Nigeria was re-structured and unlimited passion for learning was ignited. Terhemba (2007) noted that many Nigerians could not have access to higher education due to high level of poverty, illiteracy and the absolute neglect of the rural dwellers who formed a significant proportion of the country's population. Higher education became unaffordable to the low-income earners who struggled hard and-to manage-be able to attend the public primary and secondary schools. What look like the turning point was recorded in July 22, 1983 when the open university act, which subsist in the law of the Federation of Nigeria (1980) volume xvii became operational. The operation of NOUN was however suspended indefinitely on April 25, 1984. Subsequent governments were unable to lift the suspension for over 15 stormy years before President Olusegun Obasanjo did a ground-breaking opening ceremony for the full take-off of National Open University of Nigeria in Lokoja in the year 2002.

It is instructive to worth note-noting that the history of ODL in Nigeria is far pre-dated the year 1983 or 2002. A comprehensive history of distance education in Nigeria dates back to the era of correspondence education as a means of preparing candidates for the General Certificate in Education (GCE), a prerequisite for the London Matriculation Examination. Hence, the University of London has been termed the first "Open University" in the world (Tait, 2003). Students all round the world, but principally within the British Empire and its dominions, sought for tutorial support to supplement the bare syllabuses which they received on registration wherever they lived (Terhemba 2007).

4. Table 1a: Tabulation of some Historical Development of ODL in Nigeria

\begin{tabular}{|r|l|l|l|}
\hline SN & INSTITUTIONS & $\begin{array}{l}\text { DESCRIPTION OF ODL } \\
\text { PROGRAMME }\end{array}$ & REMARKS \& DATE \\
\hline 1 & $\begin{array}{l}\text { Emir of Bida, Mallam } \\
\text { Muhammad Bashir }\end{array}$ & $\begin{array}{l}\text { Adopted traditional distance learn- } \\
\text { ing mode to keep in constant touch } \\
\text { with their subjects to oppose colonial } \\
\text { rule }\end{array}$ & $\begin{array}{l}\text { Vehemently oppose colonial } \\
\text { subjugation. Deposed and } \\
\text { banished to Lokoja in 1901. } \\
\text { Grave-Burial ground,now } \\
\text { tourist centre in Lokoja }\end{array}$ \\
\hline 2 & $\begin{array}{l}\text { Emir of Zaria, Mallam } \\
\text { Aliyu Danside }\end{array}$ & $\begin{array}{l}\text { Adopted traditional distance learn- } \\
\text { ing } \\
\text { mode to keep in constant touch with } \\
\text { their subjects to oppose colonial rule }\end{array}$ & $\begin{array}{l}\text { Vehemently oppose colonial } \\
\text { subjugation. Deposed and } \\
\text { banished to Lokoja in 1903. } \\
\text { Grave now tourist centre in } \\
\text { Lokoja }\end{array}$ \\
\hline 3 & Eliyu Abdullah & $\begin{array}{l}\text { Adopted traditional distance learn- } \\
\text { ing } \\
\text { mode to keep in constant touch with } \\
\text { their subjects to oppose colonial rule }\end{array}$ & $\begin{array}{l}\text { Vehemently oppose colonial } \\
\text { subjugation. Deposed and } \\
\text { banished to Lokoja in 1903. } \\
\text { Grave now tourist centre in } \\
\text { Lokoja }\end{array}$ \\
\hline 5 & University of London & $\begin{array}{l}\text { External students studied through } \\
\text { Correspondence programme for } \\
\text { London Matriculation Examination }\end{array}$ & $\begin{array}{l}\text { Some Nigerians such as } \\
\text { Eyo-Ita,H.O. Davies bene- } \\
\text { fited in the programme since } \\
\text { 1925 }\end{array}$ \\
\hline 5 & University of London & $\begin{array}{l}\text { London Degree in Philosophy } \\
\text { through correspondence programme }\end{array}$ & $\begin{array}{l}\text { E.O. Ajayi, Alvan Ikoku and } \\
\text { J.S. Ogunlesi benefited in } \\
\text { the ODL programme in } \\
\text { 1927, 1929 and 1933 respec- } \\
\text { tively }\end{array}$ \\
\hline
\end{tabular}

Table 1a. Extracted from Terhemba (2007) 
Similarly, Omolewa as cited in Aderinoye and Ojekheta (2003) also reported that Nigerians as far back as 1887, enrolled for the first time in the University of London Matriculation Examinations as external students studying through correspondence, and without enjoying any formal ties with the educational institution. A summary of some historical development and growth of ODL in Nigeria is presented in Table $1 \mathrm{a}$ and $1 \mathrm{~b}$.

5. Table 1b: Tabular representation of some phases of ODL Historical Development of ODL in Nigeria

\begin{tabular}{|c|c|c|c|}
\hline SN & INSTITUTIONS & $\begin{array}{lll}\text { DESCRIPTION } & \text { OF } & \text { ODL } \\
\text { PROGRAMME } & & \\
\end{array}$ & REMARKS \& DATE \\
\hline 7 & $\begin{array}{l}\text { Nigeria Broadcasting } \\
\text { Corporation \& National } \\
\text { Television of Nigeria \& } \\
\text { Radio Nigeria }\end{array}$ & $\begin{array}{l}\text { English by Radio Distance } \\
\text { Learning Programme and Educa- } \\
\text { tional Television Programme }\end{array}$ & $\begin{array}{l}1^{\text {st }} \text { Indigenous distance- } \\
\text { learning programme after in- } \\
\text { dependence }\end{array}$ \\
\hline 8 & $\begin{array}{l}\text { University of Nigeria, } \\
\text { Nsukka }\end{array}$ & $\begin{array}{l}\text { Planned distance-oriented program } \\
\text { for non-residence-based students } \\
\text { through correspondence, radio, } \\
\text { television and vacation course } \\
\text { instruction in } 1981 .\end{array}$ & $\begin{array}{l}\text { The plan was put aside as the } \\
\text { Open University was then in } \\
\text { the horizon. Ojo (1984) }\end{array}$ \\
\hline & $\begin{array}{l}\text { Obafemi Awolowo } \\
\text { University (University } \\
\text { of Ife }\end{array}$ & $\begin{array}{l}\text { Part-time Evening Law } \\
\text { programme for non-residents' } \\
\text { adults' students. Faculty of Educa- } \\
\text { tion, Agriculture and Administration } \\
\text { run Outreach programme for dis- } \\
\text { tance-based Students. }\end{array}$ & $\begin{array}{l}\text { Run open education pro- } \\
\text { gramme but failed to adopt } \\
\text { distance-teaching techniques }\end{array}$ \\
\hline 9 & $\begin{array}{l}\text { Ahmadu Bello } \\
\text { University }\end{array}$ & $\begin{array}{l}\text { Pioneered the distance teaching of } \\
\text { Grade II and III teachers for-to enable } \\
\text { teachers to take their careers upgrade } \\
\text { to the next level. Correspondence } \\
\text { programme called TISEP -Teachers- } \\
\text { In-Service Education Program }\end{array}$ & $\begin{array}{l}\text { TISEP was prepare in } 1976 \\
\text { to prepare middle level } \\
\text { teachers for Nigeria's Pri- } \\
\text { mary School. }\end{array}$ \\
\hline 10 & University of Lagos & $\begin{array}{l}\text { Established Correspondence and } \\
\text { Open Studies Unit in } 1972 \text { using a } \\
\text { residence-Based method. It was later } \\
\text { upgraded to COSIT and currently } \\
\text { called Distance Learning Institute }\end{array}$ & $\begin{array}{l}\text { Distance learning technique } \\
\text { not fully implemented as all } \\
\text { DLI students are made to } \\
\text { converge at the main campus } \\
\text { for facilitation and examina- } \\
\text { tion }\end{array}$ \\
\hline 11 & $\begin{array}{l}\text { National Teachers Insti- } \\
\text { tute }\end{array}$ & $\begin{array}{l}\text { Considered as the first single mode } \\
\text { experiment with distance education } \\
\text { In Nigeria. It was designed to im- } \\
\text { prove the quality of primary school } \\
\text { teachers in Nigeria }\end{array}$ & $\begin{array}{l}\text { It was officially established } \\
\text { in } 1978 . \text { It has trained } 100 \text { of } \\
\text { thousands of teachers since } \\
\text { inception. It is now affiliated } \\
\text { to NOUN to run degree pro- } \\
\text { gramme in some courses. }\end{array}$ \\
\hline 12 & $\begin{array}{l}\text { National Open Univer- } \\
\text { sity of Nigeria } \\
\text { (NOUN) }\end{array}$ & $\begin{array}{l}\text { The first National Single-mode Uni- } \\
\text { versity that has over } 70 \text { study centres } \\
\text { across the country and licensed to } \\
\text { award degrees up to PhD level on all } \\
\text { accredited programmes. It ensures } \\
\text { equity, equality, cost effective, life- } \\
\text { long and functional education }\end{array}$ & $\begin{array}{l}\text { It was launched in } 1983 \text {, sus- } \\
\text { pended in } 1984 \text { and re-vital- } \\
\text { ized in the year } 2002 \text {. It has } \\
\text { over } 500,000 \text { students, and } \\
\text { has the capacity to take more } \\
\text { students with adequate de- } \\
\text { ployment if intensive ICT } \\
\text { tools. It has all the character- } \\
\text { istics of open and distance } \\
\text { education, similar to ad- } \\
\text { vanced ODL institutions } \\
\text { across the globe. }\end{array}$ \\
\hline
\end{tabular}


Table 1b. Extracted from Terhemba (2007)

It can be deduced from this historical documentation that most of the earliest courses offered through distance education are-were majorly mostly in the realm of Arts, Humanities and Education. Physical science courses like physics and chemistry were hardly offered despite their significance for scientific and technological advancement and long-term years of existence as a body of knowledge. The Rreasons for this exclusion is are yet to be revealed eited in any known the modern literature of nowadays. However, the perceived difficult nature of physics and its mathematical complexity which still exists till todayeven to this day, possibly -is presumably the reason why it is not made it impossible to be-offered as purely distance learning programme. Despite this perception, some ODL institutions struggled to float Physics science and Physics Education as independent programme of study with the deployment of available resources, which may be considered insufficient for open and distance environment. It is imperative to note that no nation can survive the modern world without paying due attention to the study of physical sciences like physics. Due to this huge relevance, the National Open University of Nigeria also runs a degree programme in physics education as a way of contributing to the manpower development in the study of science in Nigeria.

\section{The Reality of Physics Education in an ODL Environment}

Physics Education is generally made up of two components parts. The physics science content and the pedagogy. The pedagogical training given to all prospective science teachers in all the science education programmes have unified contents. Perhaps, the exception might be in the realm of the subject methods. Numerous educational courses have been injected into the science teachers' curriculum to enhance their capacity for instruction delivery. Table $2 \mathrm{x}$-rayed the analysis of courses that prospective physics education students must undertake before the award of Bachelor of Science in Physics Education.

7. Table 2: 2019_2 Registrable Courses for Physics Education, NOUN.

\begin{tabular}{|c|c|l|c|}
\hline S/N & COURSE CODE & COURSE TITLE & HOST \\
\hline \multicolumn{2}{|c|}{ A. EDUCATION/PEDAGOGICAL COURSES } \\
\hline 1 & EDU111 & Foundations of Education & $\begin{array}{c}\text { Faculty of } \\
\text { Education }\end{array}$ \\
\hline 2 & EDU112 & Professionalism in Teaching & FOE \\
\hline 3 & EDU114 & History of Education in Nigeria & FOE \\
\hline 4 & EDU231 & Curriculum Theory \& Practice & FOE \\
\hline 5 & EDU233 & General Teaching Methods & FOS \\
\hline 6 & EDU256 & Physics Methods & FOS \\
\hline 7 & EDU212 & Sociology of Education & FOE \\
\hline 8 & EDU214 & Philosophy of Education & FOS \\
\hline 9 & EDU216 & Micro Teaching & FOE \\
\hline 10 & EDU321 & Psychology of Learning & FOE \\
\hline 11 & EDU335 & Teaching Practice I & FOE \\
\hline 12 & EDU332 & Educational Technology & FOE \\
\hline 13 & EDU314 & Comparative Education & FOE \\
\hline 14 & EDU336 & Post Teaching Practice Evaluation & FOE \\
\hline 15 & SED324 & School Science Laboratory & FOE \\
\hline 16 & EDU 302 & ICT in education & FOE \\
\hline 17 & SED305 & Practicum in Science Education & FOE \\
\hline 18 & EDU421 & Guidance and Counseling & FOE \\
\hline 19 & EDU423 & Measurement and Evaluation & FOE \\
\hline 20 & EDU435 & Teaching Practice II & FOE \\
\hline 21 & SED 413 & Science, Technology and Society & FOE \\
\hline 22 & EDU412 & Principles of Educational Management. & FOE \\
\hline 23 & EDU420 & Research Project & FOE \\
\hline 24 & EDU426 & Special Education & FOE \\
\hline 25 & EDU323 & Basic Research Methods in Education & FOE \\
\hline & B. & GENERAL STUDIES & Page \\
\hline
\end{tabular}




\begin{tabular}{|c|l|l|l|}
\hline 1 & GST101 & Use of English and Communication Skills 1 & CEGS \\
\hline 2 & GST103 & Computer Fundamentals & CEGS \\
\hline 3 & GST107 & A Study Guide for the Distance Learner & CEGS \\
\hline 4 & GST102 & Use of English and Communication Skills 2 & CEGS \\
\hline
\end{tabular}

8. Table 2b: 2019_2 Registrable Courses for Physics Education, NOUN.

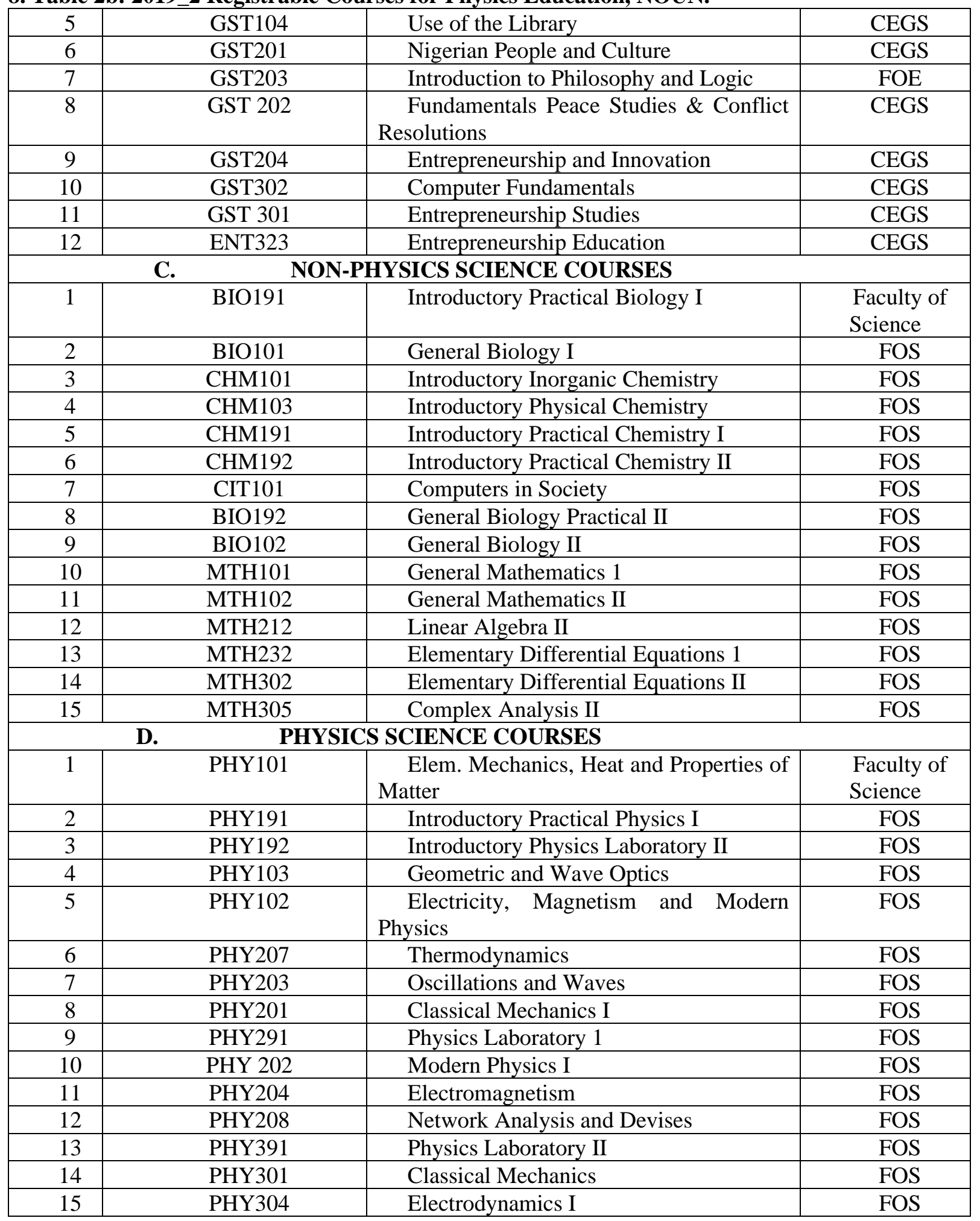




\begin{tabular}{|l|l|l|l|}
\hline 16 & PHY311 & Kinetic Theory and Statistical Mechanics & FOS \\
\hline 17 & PHY307 & Solid State Physics I & FOS \\
\hline 18 & PHY302 & Modern Physics II & FOS \\
\hline
\end{tabular}

9. Table 2c: 2019_2 Registrable Courses for Physics Education, NOUN.

\begin{tabular}{|l|l|l|l|}
\hline 19 & PHY305 & Energy & FOS \\
\hline 20 & PHY312 & Mathematical Methods for Physics 1 & FOS \\
\hline 21 & PHY314 & Numerical Computations & FOS \\
\hline 22 & PHY308 & Electronics I & FOS \\
\hline 23 & PHY 403 & Electrodynamics II & FOS \\
\hline 24 & PHY407 & Solid State Physics II & FOS \\
\hline 25 & PHY457 & Environmental Physics & FOS \\
\hline 26 & PHY455 & Lower Atmospheric Physics & FOS \\
\hline 28 & PHY451 & Ionospheric Physics & FOS \\
\hline 30 & PHY402 & Nuclear Physics & FOS \\
\hline 31 & PHY452 & X-Ray Crystallography & FOS \\
\hline
\end{tabular}

Further analysis of the 83 courses shown in table 2 revealed that 25 of the total courses offered in physics education, which represent $30.12 \%$ of the distribution are meant to sharpen the pedagogical thought and methodology of the pre-service physics teachers during their professional training. A total of 31 physics courses which amount to $37.35 \%$ of all the total-courses effered-provided are to be taken by the students to enhance their content proficiency in physics.

Table 2: Analysis of Physics Education Courses

\begin{tabular}{|c|c|c|}
\hline $\begin{array}{c}\text { CATEGORIZATION OF } \\
\text { PHYSICS EDUCATION COURSES }\end{array}$ & $\begin{array}{c}\text { NO-No OF } \\
\text { COURSES }\end{array}$ & $\begin{array}{c}\text { PERCENTAGE (\%) } \\
\text { DISTRIBUTION }\end{array}$ \\
\hline Pedagogical Courses (A) & 25 & $30.12 \%$ \\
\hline Courses in General Studies (B) & 12 & $14.46 \%$ \\
\hline Non-Physics Science Courses (C) & 15 & $18.07 \%$ \\
\hline Physics Science Courses (D) & 31 & $37.35 \%$ \\
\hline Total & 83 & $100 \%$ \\
\hline
\end{tabular}

The 12 university general courses which represents $14.46 \%$ must also be passed by the physics education students before they can be qualified for the award of BSc. (Ed.) Physics degree of National Open University of Nigeria. This submission is in line with the minimum benchmark of National University Commission (NUC) which regulates the operation and management of university education in Nigeria.

The level of enrollment into the department of Arts and Social Science and the Department of Educational Foundation, which offered very similar pedagogical educational courses as well as the 12 courses in General Studies, is higher than the enrollment into science education. Going by the statistical data obtained from the Directorate of Management Information System of National Open University of Nigeria (NOUN-MIS), covering a five year period between 2015 and 2019, a total of 5,061 enrolment was recorded for the Department of Educational Foundation which housed Primary and Early Childhood Education Programme at the undergraduate level while a total of 5,903 was captured for the Department of Art and Social Science Education, with specific attention on English Language and Business Education programme. One might be compelled to admit that the trend has been like that since time immemorial and that the level of enrollment into Arts and Commercial classes is usually higher than the science class right from the secondary school.

The Department of Science Education, which is made up of Physics, Chemistry, Biology, Agricultural Science, Mathematics and Computer Education programme had the lowest enrolment figure of 3,904. Further analysis of students' enrolment in the Department of Science Education revealed that Physics education had the lowest enrolment figure of 5.3\% while Biology Education had the highest enrolment 
figure of $40 \%$. Computer Science Education pulled 20.5\%, Agricultural Science had $14.1 \%$ while Mathematics Education got 12.8\% enrolment figure (NOUN-MIS, 2020). During this period, enrolment figure for Physics Science was higher than that of Physics Education with 519 and 207 respectively. In the usual characteristics of enrolment into physics related programme, physics science had the least enrolment figure in the Faculty of Science. While Biology and Chemistry pulled 3,644, 939, respectively, Physics science had 519 enrolment figure. Similarly, the graduation figure between the year 2015 and 2019 as released by NOUN-MIS (2020) showed that a paltry figure of $4.1 \%$, representing 35 students of the total 853 students, who graduated within the five-year duration in the Department of Science Education are physics Education Students. In this conservative figure, a total of 346, representing $40.6 \%$ was for the Biology Students. In all fronts, both the enrolment and graduation of students in physics education has always been very low.

In a related study, which focus on students' enrolment into College of Education Technical, Lafiagi, Kwara State, between the year 2012 and 2016, Ayodele and Aina (2018) remarked that out of 3,174 students admitted for Biology, Chemistry and Physics Education courses, 68.9\% of the enrolment was for Biology Education, 22.4\% opted for Chemistry Education while a paltry meagre enrolment of $8.7 \%$ settled for Physics Education.

Mbamara and Eya (2015) also observed that despite the significance and relevance of physics towards the nation's technological and scientific development, students' enrolment for physics has been on the decline. Consequently, students' enrolment into the department of physics and physics education has been very low since the few handful of students who offered physics at the senior secondary school certificate level often pitch their interest in medicine, engineering and other seemingly prestigious and lucrative field of study (Mbamara \& Eya, 2015). In comparison, the enrolment figure for biology and chemistry science is better than that of the physics (Mbamara \& Eya, 2015; Ayodele and Aina, 2018). At the global level, Samela (2010) and Taale (2011) attested to the fact that the situation under discussion is a tniversatworldwide challenge. The main reason for concern in this study is that the gap keeps widening as the students approach higher learning. Some science-oriented students also drop their career path in science and switch-over to Arts and Foundations and other management courses due to the perceived phobia for the physical sciences (physics and chemistry), especially in the open and distance learning environment. Physics education has been badly affected by this development. The few diminishing number of the science students who eventually make it to the department of science education often opted for Biology, Agricultural, Computer Science education courses. Physics education is always the last in order of preference.

This trend needs to be consciously and deliberately checked considering the huge significance of physics towards the scientific and technological independence of this nation. Countries Most nation of throughout the world are finding have been insisting on the urgency of an early solutions to the ehallenge of ongoing acute shortage of qualified physics teachers. Nigeria must not be an exception. It must however be mentioned that the phenomenon of very low enrollment into physics education programme is also similar in the conventional universities across the country. Most physics education students often accept the programme as their last available option and later on support the struggle for survival in the programme with strong determination and change of attitude. This is agreement with the philosophy that says "if the preferred is not available, the available becomes the preferred. Only very few of these students consciously and willingly epted-made their choice to study physics education despite the perceived challenges. The situation of poor enrolment becomes more pronounced in an open and distance environment where the culture of daily interaction with tutors or lecturers is not possible.

The main challenge for poor enrollment in physics education can also be traced to the perceived difficult nature of the 31 physics science courses and the 15 non-physics science courses outlined in table 1 . Most of the courses are extremely abstract in nature and too mathematical if there are no laboratory practical components to support its learning. Most physics students embark on complex rote learning method to survive the study of physics in an open and distance learning environment. Lambourne (2007) noted that dealing with hierarchical nature of physics knowledge, including the need for increasingly sophisticated mathematics as studies progresses in distance learning environment might be a huge challenge. This can however be mitigated with adequate and appropriate practical work to develop experimental and investigative skills required in the study of physics.

Moving away from the idealistic world into a more realistic environment of truth, it may be difficult for students of physics to be grounded and proficient in his knowledge of physics without relevant 
exposure to practical and laboratory activities when dealing with most of the topics in physics curriculum. Learning according to most of the psychologists must begin from concreteness and migrate gradually into abstractness. Topics such as Nuclear Physics, Electronics, Thermodynamics, Solid State Physics, X-Ray Crystallography, Electrodynamics and many others require more than mere theoretical presentation in the course materials. It is instructive-important to note that, on the whole, the same-way this dreaded but compulsory subject was taught at the secondary school level is-was been-replicated and adopted in exactly the same way at the higher level of learning. Most of the practical exercise carried out during the physics laboratory class are mere repetition of senior secondary school low-level physics practicals (Triangular and Rectangular glass prism experiment, Simple pendulum experiment, experimental verification of ohm's law, determination of mass of a meter rule through balancing etc.) These practical activities may however be new to some students who never had the opportunity in their secondary school days. The argument in this discourse is that physics of the $21^{\text {st }}$ century has gone far beyond the current practical activities that is been carried out are performed in most of our college laboratories.

It must however be made known that the problem of shortage of physics teachers is a global phenomenon. Despite the level of scientific and technological awareness of United of America, the country is also battling with the challenge of long-term shortage of qualified physics teachers (AAEE, 2010). In 2013, the National Task Force on Teacher Education reported that "the need for qualified physics teachers is greater now than at any previous time in U.S. history (PhysTEC, n.d.). In Nigeria, qualified physics teachers are-would be hard to come by. Most secondary school physics teachers are either graduates of engineering of related science courses. This is because enrollment into physics education programme is generally low across all Nigerian Universities and particularly in National Open University of Nigeria. Going by the statistics of the physics education students who participated in the 2019_2 Science Education Practicum (SED305), only five students were harvested by NOUM-Management Information System (MIS) and only one student from Abeokuta Study Centre eventually participated in the course. This is highly worrisome. It should be noted that lack of qualified physics teachers leads to uninspired and unsuccessful students who do not choose to do physics. Hence, the society get fewer physics graduates and so fewer specialist teachers and the cycle continues. Once physics starts being is removed as an option in the curriculum of science students, then the rot has-will truly set in.

To solve this challenge of inadequacy of physics teachers in Morocco and Malaysia, open and distance learning system was adopted for deliberate massification of physics educars-education across the two countries (Kumar, Subramaniam, \& Mukherjee, 2005) This adoption of ODL as a tool for the preparation and training of physics teachers is also a clear indication that the continuous struggle for survival of physics education at the mark of 15 years of National Open University of Nigeria will eventually be successful.

\section{Laboratory Practicals for ODL Physics Education Students - The Paradigm Shift}

The year 2019 marks the beginning of what could be termed as paradigm shift in laboratory practicals for science-based students of National Open University of Nigeria. The Faculty of Science launched the first Mobile Laboratory Practical Exercise across the six geo-political zones of the country in the operation "move the Laboratory to the Zones". Science practical apparatus for physics, chemistry, biology, mathematics, computer and environmental science were moved down to the designated centres in each of the six geo-political in Nigeria for a duration of three weeks. These zones are North-East, North-West, NorthCentral, South-East, South-South, and South-West. Science students from the study centres were scheduled to participate in the practical activities in line with their course of study. This was indeed a huge achievement for the physics education students in particular and National Open University in general. The mobile laboratory concept of NOUN towards solving the challenges of distance learners practical exercise is however at variance with that of Malaysia Open University, (MOU).

MOU rented the laboratories of other conventional universities that are spread across the country to execute their science practical activities. The huge cost implication of this model truncated-curtailed the provisions the earlier memorandum of understanding signed with some conventional universities in $\mathrm{Ni}$ geria. In any case, the ultimate objective of both the Mobile Laboratory of NOUN and the Rented arrangement of MOU is to ensure that science education students in open and distance learning environment have quality access to relevant practical activities. Kumar et. al. (2005) noted some challenges that impeded the smooth execution of the science practical for distance learning science students. Some of these challenges include problem of rural area accessibility, students outnumbered the available facilities, non- 
compliance of students to scheduled date and time, renumeration issue with ad-hoc staff for the exercise among others. Mobile laboratory model of engaging distance learners in science practical exercise was also accompanied with some difficulties. Moving sensitive and fragile laboratory apparatus could results into a lot of damages as it was experience in the case with the last practical exercise.

It must be admitted however, that both the mobile and rented laboratory models are premised on conventional method of laboratory exercise due to their absolute reliance on the existence of physical laboratories. This long-standing limitation has necessitated a massive deployment of information and communication technology tools for distance learners. Kumar et. al. (2005) enumerated five major category of ICT driven methods of instructional delivery in distance education. These include:

1. The use of Interactive DVDs and CDs: These interactive CDs can be deployed for individualized instruction. Pre- recorded video clips of physics laboratory practical can be viewed by physics education students to learn the appropriate practical exercise.

2. On-line Tutoring or Facilitation: On-line facilitation can be achieved through several e-learning platform. Prominent among these platforms are Moodle, Edmodo, Schoology, Google Class etc. Besides the exposure to laboratory practical activities, these platforms can be used to convey instructions in physics and other pedagogical courses in education. It enables facilitators and learners to have face-to-face classroom interaction in a virtual environment. Physics education students can view engoing the latest activities, ask questions on those areas that are not clear from the facilitators and possibly interact with other learners. Such activities can generate new ideas and cultivate innovations.

3. Virtual Laboratory: This is an interactive environment for creating and conducting simulated experiments. Physics experiments can be simulated close to a real-world situation in a virtual environment using computer technologies such as JAVA, an interactive multimedia programming language via internet. The virtual laboratory allows the students to be actively involved in the experimental process at their own pace. Physics students can be exposed to various types of experiments involving sophisticated apparatus and instruments (Ogunleye \& Apata, 2018).

4. Self-Built Experimental Project: Kumar et. al. (2005) noted that real-time experimental experience is required to complement the virtual experience. This can be achieved through home experiment or low-cost commercial experimental kits. This is to emphasize the fact that physics is better learnt through laboratory and experimental activities.

5. Laboratory Session: Students are required to perform experiments in a designated laboratory (either mobile or rented) for the primary purpose of ascertaining the effectiveness of the other distance learning tools earlier mentioned and also assess the quality of their reports. Physics education students will only need to attend a single practical session for this purpose.

Kumar (2007) asserted that the five models proposed for practical activities for distance learners are highly student-centered. Physics education students will be able to study anytime, anywhere and at their own pace. The model further enables incorporation of interactive features that can make the learning process a fascinating experience, especially through the usage of 3-D visualization. This-Moreover, these learning facilities are-entirely in tme consistent with the philosophy of open and distance learning. In the light of the above submission, Physics education as a course of study can be better positioned to survive the open and distance environment if the relevant ICT facilities are adequately deployed for the benefits of physics education students.

\section{Recommendations}

1. The National Open University of Nigeria Advocacy Team should collaborate with the Department of Science Education on taking aggressive sensitization and campaign to the secondary school science students on the prospects and economic gains of physics education

2. NOUN should, as a matter of necessity consolidates on the gains of 2019 Mobile Laboratory Practical Exercise across the six geo-political zones by deploying other e-learning facilities such as the virtual laboratory platform to enhance continuous practical exercise for physics students and other science students in general 
3. The Government and other concerned stakeholders in science education should consciously and deliberately attract science students towards the study of physics education by introducing certain incentives such as scholarship and bursary awards for outstanding physics education students.

4. Continuous and concerted research effort should be ensured towards making the learning of physics and other related science subjects much more interesting and convenient to learn in secondary school.

\section{Conclusion}

Open and distance education has been adopted by developed societies like United Kingdom, Malaysia, India, South Africa and several others for the massification of skilled manpower, among whom are physics educators. The enrollment of prospective physics teachers into physics education programme, particularly at the National Open University of Nigeria, could be better enhanced through open and distance education if the relevant and modern distance learning facilities are appropriately deployed. Then, the struggle for survival of physics education programme fifteen years after the establishment of the University would be a bitter memory of the past not has ever been imagined.

\section{References}

Amadalo, M. M., Ocholla, A. A. \& Memba, E. B. (2012). Effect of Practical Work in Physics on Girls' Performance, Attitude and Skills acquisition in the two-form three Secondary Schools' transition in Kenya. International Journal of Humanities and Social Science 2(23), 151 - 166.

American Association for Employment in Education, Inc., 2010 Executive Summary: Educator Supply and Demand in the United States (AAEE, Columbus,OH, 2010).

Amusa, J. O. (2015). Physics Education as a Bedrock of Peace and National Development. NOUN Journal of Education. 2, 129- 138.

Amusa, J. O. (2015). Physics Education - A Bedrock of Healthy Society and Sustainable Development. International Journal of Research in Science, Technology and Mathematics Education 3(1), 173 - 184.

Ayodele, M. O. \& Aina, J. K. (2018). Science Education and Students' Enrolment in Colleges of Education in Nigeria. A Paper presented at the $9^{\text {th }}$ National Conference for the Teacher Education and Students' Enrolment in Colleges of Education in Nigeria at Adeyemi College of Education, Ondo, Nigeria, between $12^{\text {th }}-15^{\text {th }}$ March 2018.

Federal Republic of Nigeria (2011). National curriculum for senior secondary schools. Volume 3 Science. Lagos.

Khalid, M., Mohammed, C. \& Mohamed, L. (2014). Distance Training for Physics Teachers in Education Sciences: Flexible and Efficient. International Journal of Scientific Research \& Engineering Technology (IJSET), Ravi Mittal, 2014, 5 (1), 77. ffhal-01437060f

Jegede, S. A., Adedayo, J. O. (2013). Enriching Physics Education in Nigeria Towards Enhancing a Sustainable Technological Development. Greener Journal of Educational Research 3 (2), 080-084. https://doi.org/10.15580/GJER.2013.2.013113424

Jegede, O. J. (2003a). Taking the Distance Out of Higher Education in $21^{\text {st }}$ Century Nigeria. An Invited Convocation Lecture Presented at the Federal Polytechnic Oko, Anambra State on the $28^{\text {th }}$ of November 2003.

Kumar, P. R., Subramaniam, T. \& Mukherjee T.K.M (2005). Issues in Physics Practicals in An Open and Distance Learning Environment. Asian Journal of Distance Education 3(1).

Lambourne, R. (2007). Laboratory-based teaching and the Physics Innovations Centre for Excellence in Teaching and Learning, Eur. J. Phys. 28 S29-36. https://doi.org/10.1088/0143-0807/28/3/S03

Mbamara, U. S., \& Eya, P. E. (2015). Causes of Low Enrollment of Physics as a Subject of Study by Secondary School Students in Nigeria: A Descriptive Survey. International Journal of Scientific Research in Education, 8(4), 127-149. Retrieved [7 June, 2020] from http://www.ijsre.com.

National Open University of Nigeria-Management Information System (NOUN-MIS) (2020). Students Enrolment and Graduation Data, Received on 8th June, 2020. 
Ogbeide, C. (2019). Challenges of Open and Distance Learning (ODL) for Functional Education in Nigeria. Journal of Emerging Trends in Educational Research and Policy Studies (JETERAPS) $10(1), 56-61$

Ogunlela, V. B. and Ogunleye, B. O. (2014). Promoting quality assurance practices for ODL programmes in West African higher education institutions: The role of RETRIDAL. International Open and Distance Learning Journal. $4^{\text {th }}$ ACDE 2014 Special Edition, 95-108.

Ogunleye, B. O. (2009). Students' background in science, mathematical ability and practical skills as determinants of performance in senior secondary school chemistry. African Journal of Educational Management, 12 (2), 215-226

Ogunleye, B. O. (2009). Integration of contemporary ICT tools in the teaching of Chemistry: Awareness and attitudes of Chemistry teachers in South West, Nigeria. Journal of e-Learning, 8 (2), 118.

Ogunleye, B. O. \& Apata, F. S. (2018). Integrating intelligent pedagogical agents into learning management systems for student exposure to science experiments in the National Open University of Nigeria. Kampala International University Journal of Education, 13 (2), 31-51.

Ogunleye, B. O. (2011). Trends and patterns of Nigerian students' WASSCE entry and performance in physics, chemistry and biology (2000-2009). African Journal of Historical Sciences in Education, 7(2), 331-344.

Ogunleye, B. O. (2012). Relationship among teachers' science process skills, scientific attitudes and students' performance in Chemistry. International Journal of Educational Leadership, 4 (4), 41-48.

Ogunleye, B. O. (2010). Computer literacy and attitude to computer as predictors of chemistry teachers' utilization of computer technology in selected Nigerian schools. African Journal of Educational Research, 14 (1 \& 2), 20-29.

Ojo, G. A. (1984). Distance Education in Nigeria and the Emergence of the National Open University. A Valedictory Lecture; University of Ibadan. pp. 9-10.

Physics Teacher Education (n.d.). Improving the Education of Future Physics Teachers Retrieved January1 $12^{\text {th }}, 2020$ from https://www.phystec.org/webdocs/shortage.cfm.

Samela, T. (2010). Who is Joining Physics and Why? Factors Influencing the Choice of Physics among Ethiopian University Students. International Journal of Environment \& Science Education 5(3). Pp 319- 340. www.ijese.com/...

Taale, K. D. (2011). Parental and Society Influence on Physics Students' Enrolment Decisions in the University of Education, Winneba, Ghana. Journal of Education Practice 2(4). P2. www.iiste.org/...

Terhemba, N. A. (2007) National Open University of Nigeria (NOUN): A Historical Perspective and Challenges. Turkish Online Journal of Distance Education-TOJDE 8(1)6

https://doi.org/10.19173/irrodl.v8i3.458

UNESCO (2000). World Development Report 2000. Paris: UNESCO. 